\begin{tabular}{|} 
Ambiente \& Água - An Interdisciplinary Journal of Applied Science \\
ISSN 1980-993X - doi:10.4136/1980-993X \\
www.ambi-agua.net \\
E-mail: ambi.agua@gmail.com
\end{tabular}

\title{
Sensitivity analysis of the Soil and Water Assessment Tools (SWAT) model in streamflow modeling in a rural river basin
}

\author{
ARTICLES doi:10.4136/ambi-agua.2221 \\ Received: 10 Dec. 2017; Accepted: 12 Oct. 2018 \\ Luana Lavagnoli Moreira*; Dimaghi Schwamback; Daniel Rigo \\ Universidade Federal do Espirito Santo (UFES), Vitória, ES, Brasil \\ Departamento de Engenharia Ambiental. E-mail: lavagnoliluana@gmail.com, \\ dimaghis@gmail.com,rigo@npd.ufes.br \\ *Corresponding author
}

\begin{abstract}
The uncertainties present in hydrological models have made them difficult and often impossible to apply. This work evaluated the sensitivity of input parameters in the SWAT model used for the modeling of average monthly flow-discharge in the Jucu River Basin, located in the southeast portion of the state of Espírito Santo, Brazil. Sensitivity analysis was performed using the SWAT-CUP program, which uses the SUFI-2 algorithm. Four sensitivity analysis tests differing by the length of hydrological series, number of iteration and fluviometric station locations resulted in different sensitivity levels of input parameters used in the model. In this way, the present study emphasizes the need for a greater detailing of methodological processes used in the sensitivity analysis, so that different hierarchies of parameters can be obtained through the same tool.
\end{abstract}

Keywords: sensitive parameters, simulation, SWAT-CUP.

\section{Análise de sensibilidade do modelo Soil and Water Assessment Tools (SWAT) na modelagem de vazões em uma bacia hidrográfica rural}

\section{RESUMO}

As incertezas presentes em modelos hidrológicos têm dificultado e muitas vezes inviabilizado sua aplicação. Este trabalho tem como objetivo a avaliação da sensibilidade dos parâmetros de entrada no modelo SWAT para a modelagem de vazões médias mensais na bacia do rio Jucu, localizado na porção sudeste do estado do Espírito Santo (Brasil). A análise de sensibilidade foi realizada por meio do programa SWAT-CUP ao qual faz uso do algoritmo SUFI-2. Quatro testes que se diferenciavam pelo tamanho da série hidrológica, escolha da estação de monitoramento de vazões e número de variações dos valores dos parâmetros durante a análise de sensibilidade resultaram em diferentes níveis de sensibilidade para os parâmetros de entrada do modelo SWAT. Desta forma, o presente estudo enfatiza a necessidade de maior detalhamento dos processos metodológicos empregados na análise de sensibilidade, tendo em vista que diferentes hierarquias de parâmetros podem ser obtidas por meio da mesma ferramenta.

Palavras-chave: parâmetros sensíveis, simulação, SWAT-CUP. 


\section{INTRODUCTION}

Hydrological models are powerful tools to represent water-resource availability and behavior in drainage basins under many applications, such as climate change, flood, drought, runoff and nutrient movement (Abbaspour et al., 2015). They can assist in the planning and decision-making processes for environment protection and the guarantee of water availability for future uses (Da Silva et al., 2015; Fatichi et al., 2016).

The Soil and Water Assessment Tool (SWAT) is a physically based, continuous-time, mathematical-hydrological model (Arnold et al., 1998). It has been initially designed to estimate water quantity and quality under different conditions over time (past, present and future) in small- and large catchments with satisfactory accuracy (Francesconi et al., 2016; Lamba et al., 2016; Zhang et al., 2016; Golmohammadi et al., 2017).

The ability of a hydrological model to produce satisfactory predictions are necessarily correlated to adequate sensitivity analysis and model calibration (Song et al., 2015). Hydrological models, such as SWAT, incorporate several parameters (pedological, climatic, hydrological and others) obtained theoretically and through field data collection. Some of these contribute greatly to model outputs (sensitive parameters), while others have minor relevance (non-sensitive parameters) (Van Griensven et al., 2006).

The calibration process of the SWAT model using all of the input variables requires a great deal of effort, money and time, whereas the removal of sensitive variables decreases the accuracy of the results (Zadeh et al., 2017; Song et al., 2015). The inappropriate removal of parameters during the sensitivity process may lead to inconsistent model results (Sahu et al., 2016).

Sensitivity analyses can be classified into local, in which changes in parameters are made one-by-one, while all the others are kept constant, and global, which promotes a multilinear regression of the entire input space (Brouziyne et al., 2017; Song et al., 2015). There are many techniques that can be applied to sensitivity analyses: manual operations, screening methods, regression analyses, variance-based methods, meta-modeling methods, and others (Song et al. 2015).

Besides the increasing of SWAT publications, only a few of the techniques focus on sensitivity-analysis improvements (Brouziyne et al., 2017). Wu and Liu (2012) proposed an automated sensitivity analysis through R-package Flexible Modeling Environment (FME). Romagnoli et al. (2017) highlighted that data availability, such as flowstream and precipitation series length, may affect the sensitivity ranking. Kouchi et al. (2017) examined the sensibility of parameters under different algorithms and objective functions, obtaining a diverse range of sensitive parameters leading to different streamflow estimations.

Some other studies done in Brazil (Da Silva et al., 2015; Pontes et al., 2016; Brighenti et al., 2016) and internationally are also relevant (Sarrazin et al., 2016; Zhang et al., 2016; Tegegne et al., 2017) when searching for regional-sensitive parameters. However, none of these has paid much attention to how procedures (number of iterations) and data input (length of historical series and fluviometric station selection) may affect the sensitivity-analysis process.

Considering this deficiency, this paper conducted a global sensitivity analysis using the Sequential Uncertainty Fitting Version 2 (SUFI2) algorithm replicated under four different scenarios differing by input variables and number of iterations. Using this procedure, we investigated how methodologies can influence the rank of sensitive parameters on the SWAT model. 


\section{MATERIAL AND METHODS}

\subsection{Hydrological modeling}

The study relates to the Jucu River Basin, located in the southeast portion of the state of Espírito Santo, which has a catchment area of $2,183 \mathrm{~km}^{2}$ (Figure 1). This area was chosen because it is the main freshwater source for more than 1.9 million inhabitants (IBGE, 2018) of the metropolitan area of Vitória (state capital), making the accurate prediction of water availability over time crucial. Additionally, the basin has a database from previous monitoring (such as streamflow, soil use, and pedology), which are required for SWAT-modeling runs.

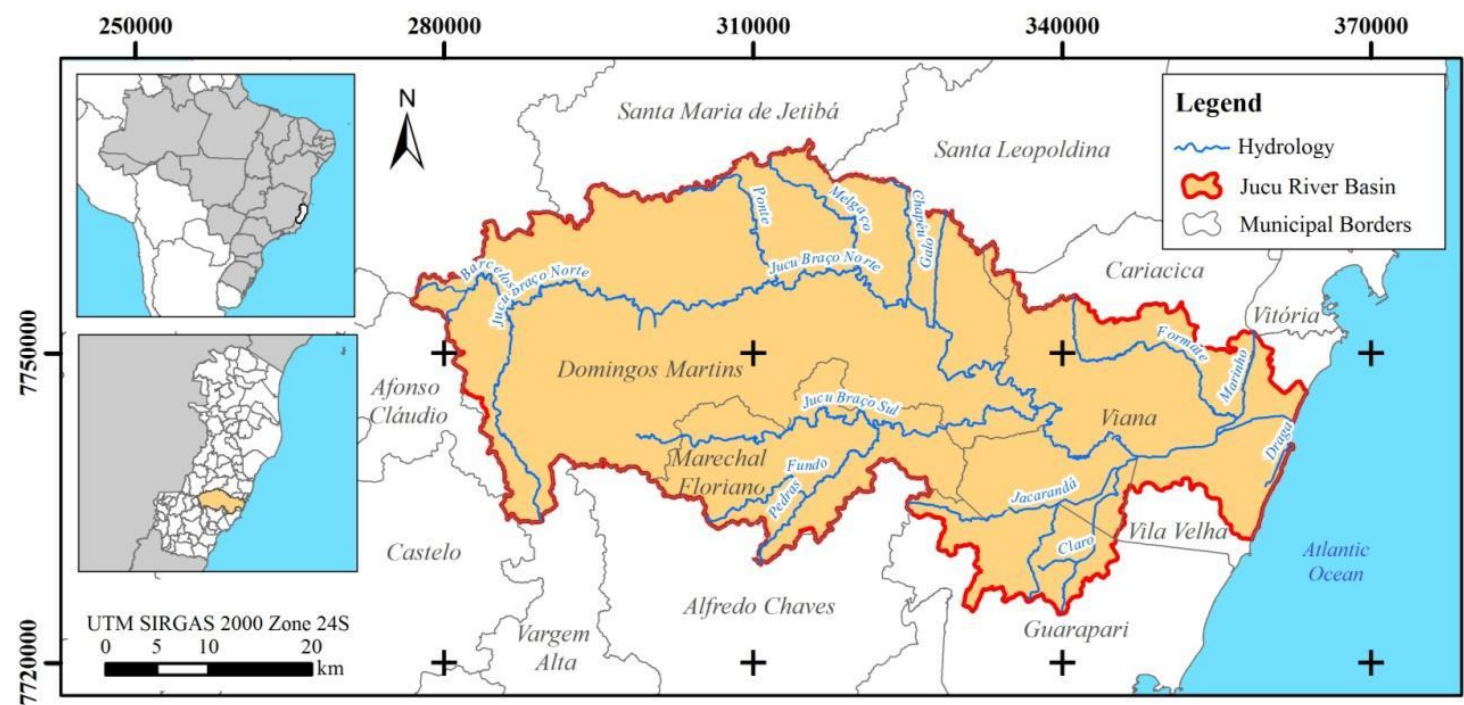

Figure 1. Location of the Jucu River Basin.

The first SWAT-modeling step involved the design of the hydrographic basin, sub-basins and drainage network by means of a digital elevation model (DEM) with a spatial resolution of 30 meters (Figure 2a) obtained by the Advanced Spaceborne Thermal Emission and Reflection Radiometer (ASTER) in 2011.

Then, physiographic data of pedology (Figure 2b), land use and occupation (Figure 2c) and classes of slopes were obtained. The soil information was acquired from a survey of soil from the state of Espírito Santo conducted in 1978 by the Brazilian Agricultural Research Corporation (EMBRAPA). The soils types found in the Jucu River Basin were:

- LVd2 - dystrophic red yellow ferralsol: A moderate clayey texture, strong corrugated relief;

- LVd3 - dystrophic red yellow ferralsol: A moderate clayey texture, and mountainous relief;

- LVd12 - dystrophic red yellow ferralsol: A moderate clayey textured, soft wavy relief;

- Cd1 - dystrophic haplic cambisol: A moderate clayey texture, and medium strong wavy mountainous relief;

- PV2 - alic acid red yellow acrisol: A moderate clayey relief texture;

- Amd2 - dystrophic arenosol: A moderate sandy flat relief;

- Ad1 - dystrophic fluvisol: A weak and moderate texture, medium plane relief;

- AR - eutrophic leptosol: A moderate texture and clayey, steep relief, mountainous and strong wavy. 
Land-use and occupation data were obtained from a survey carried out by the State Institute of Environment and Water Resources (IEMA, 2007). From the data described above, the hydrologic response units (HRU) were established.

After HRU definition, the data from climatic stations located in the study basin were inserted on the SWAT model. These data refer to solar radiation $\left(\mathrm{KJ} . \mathrm{m}^{2}\right)$, rainfall $(\mathrm{mm})$, maximum and minimum air temperatures $\left({ }^{\circ} \mathrm{C}\right)$, relative humidity $(\%)$ and wind speed $\left(\mathrm{m} . \mathrm{s}^{-1}\right)$. These data were obtained from the Capixaba Institute for Research, Technical Assistance and Rural Extension (INCAPER, 2016) and the National Water Agency (ANA, 2016).

The last stage of SWAT processing consisted of the simulation, where the warm-up period, simulation period, time-step of the monthly simulation, and output data (water production series of monthly average flows) were defined. Once the output data were determined, the sensitivity analysis of the parameters related to water production in the river basin was performed.

The sensitivity analysis used discharge data from two different fluviometric stations. The first, under code 57230000, was called "Fazenda Jucuruaba"; and the second, under code 57170000, was called "Córrego do Galo". Both are under the responsibility of the National Water Agency (ANA). The latter station covers a drainage area of $1,675.19 \mathrm{~km}^{2}$, while the former station covers $965.67 \mathrm{~km}^{2}$, as shown in Figure 2-d. The list of climatic stations, station operators, coordinates of the station, data type and respective length of historical records is shown in Table 1, arranged in turn geographically by means of Figure 2-d.

A

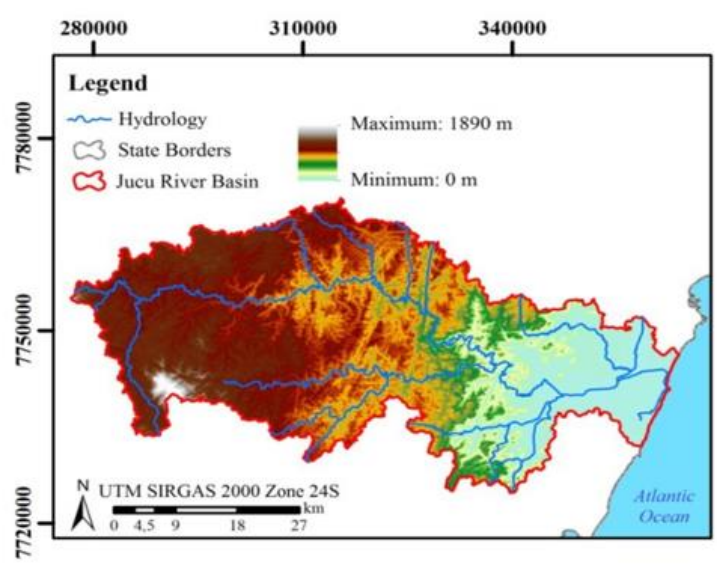

C

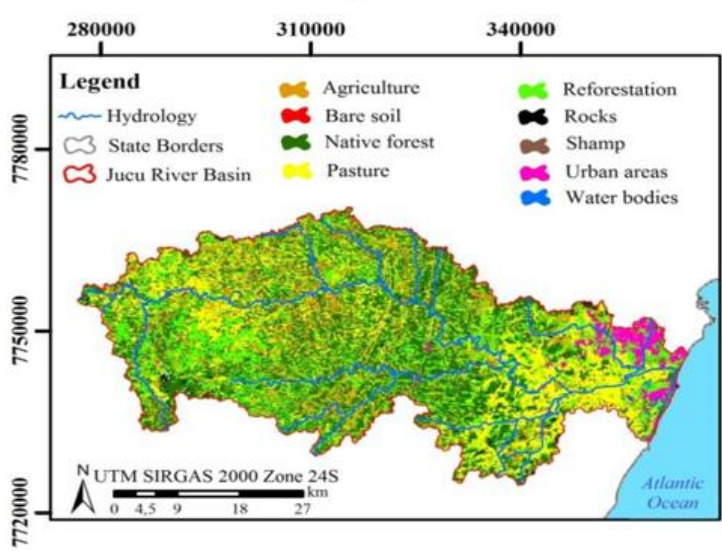

B

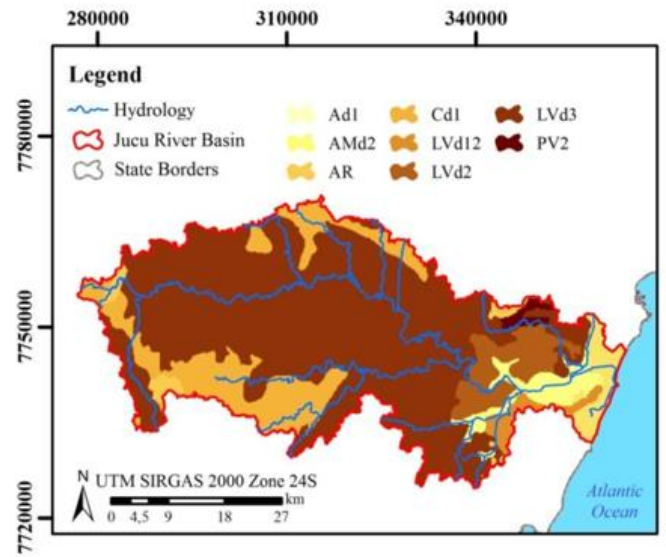

D

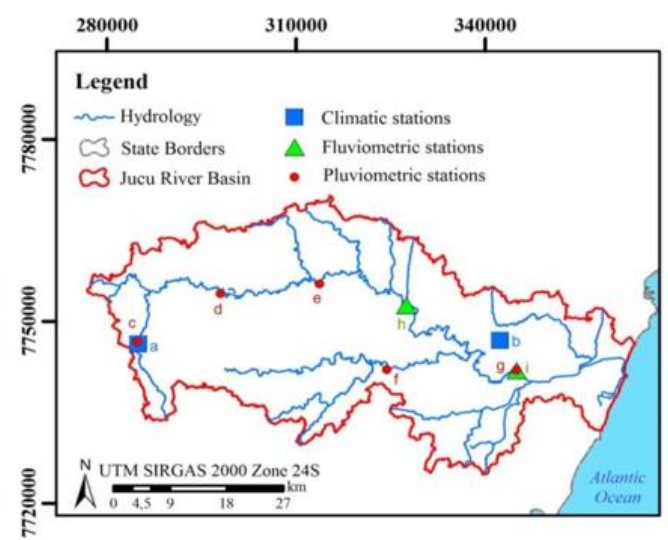

Figure 2. Map of topography (A), pedology (B), land use (C), location of climatic, fluviometric and pluviometric stations (D) in the Jucu River Basin. 
Table 1. Input data of the SWAT model.

\begin{tabular}{lcccccc}
\hline \multirow{2}{*}{ Type } & Symble & Station & \multirow{2}{*}{ Code } & Controller & \multicolumn{2}{c}{ Coordinates* } \\
\cline { 3 - 6 } Climatic & $\mathrm{a}$ & Domingos Martins & - & \multirow{2}{*}{ INCAPER } & 7745120.60 & 284999.72 \\
& $\mathrm{~b}$ & Viana & - & & 7746850.66 & 342404.53 \\
& $\mathrm{c}$ & Arace & 02041020 & & 7718808.69 & 281119.36 \\
\multirow{3}{*}{ Pluviometric } & $\mathrm{d}$ & Marechal Floriano & 02040012 & & 7716039.40 & 218592.79 \\
& $\mathrm{e}$ & Perobinha & 02040015 & ANA & 7735136.92 & 260035.13 \\
& $\mathrm{f}$ & Fazenda Jucuruaba & 02040001 & & 7709938.37 & 310756.88 \\
\multirow{2}{*}{ Fluviometric } & $\mathrm{g}$ & Marechal Floriano & 02040012 & & 7716039.40 & 218592.79 \\
& $\mathrm{~h}$ & Córrego do Galo & 57170000 & \multirow{2}{*}{ ANA } & 7752588.84 & 327516.21 \\
& $\mathrm{i}$ & Fazenda Jucuruaba & 57230000 & & 7741838.41 & 344989.90 \\
\hline
\end{tabular}

*UTM SIRGAS 2000 Zone 24S.

\subsection{Sensibility Analysis}

The sensitivity of the SWAT parameters was performed using the Sequential Uncertainty Fitting Version 2 (SUFI2) algorithm executed by the SWAT Calibration and Uncertainty Programs (SWAT-CUP) software. This process is carried out in conjunction with the calibration process, so it is necessary to include the flows estimated by the SWAT and the monitored flows. That is necessary because sensitivity is estimated according to the variations according to objective function that evaluates the model calibration's effectiveness.

The sensitivity of the parameters is computed by multiple regression systems represented in Equation 1, which returns the values of the parameters generated by the Latin hypercube sampling versus the objective function values (Abbaspour et al., 2007).

$$
g=\alpha+\sum_{i=1}^{m} \beta_{i} b_{i}
$$

where $g$ is the objective function value; $b$ is the parameter; $\alpha$ is the regression constant; $\beta$ corresponds to the technical coefficient attached to the variable $b$; and $\mathrm{m}$ is equal to the number of parameters.

The mean of the variations in the objective function estimates the sensitivity. It is computed by altering each parameter, one by one, while all other parameters remain the same. This is evaluated by the values of $\mathrm{t}$-stat and $\mathrm{p}$-value. The higher the absolute value of $\mathrm{t}$-stat and smaller the value of p-value, the more sensitive is the parameter (Abbaspour et al., 2007).

The $\mathrm{t}$-stat is the regression coefficient of a parameter divided by its standard error. If the coefficient value is greater than its standard error, the value of t-stat is greater than zero, so the parameter is sensitive (Abbaspour et al., 2015). To calculate the p-value, it is necessary to compare the value of t-stat with the values given on the t-Student distribution table. The $\mathrm{p}$-value for each parameter tests the null hypothesis that the regression coefficient is equal to zero.

A small value of $p$-value $(<0.05)$ indicates that we can reject the null hypothesis. This means that the parameter exerts influence on the dependent variable, thus it is sensitive. The value of 0.05 indicates that there is a $95 \%$ probability that a parameter change will affect the dependent variable (Abbaspour et al., 2009).

The parameters chosen for this analysis refer to those that can be adjusted and relate only to the water production in a river basin. The SWAT database presents a table of these parameters indicating their ranges of value, action plan (basin, sub-basin or HRU), form of variation of values (replace by a given value, add to the existing parameter value or relative when an existing parameter value is multiplied by), and the sensitivity-analysis group (water production, sediment yield or water quality).

\section{IPABH}

Rev. Ambient. Água vol. 13 n. 6, e2221 - Taubaté 2018 
Table 2 shows the parameters available for water production, their description, lower (LL) and upper (UL) limits for adjustments and the method of value variation. The parameter descriptions, physical properties, and lower/upper limits are detailed by Arnold et al. (2012) in Soil \& Water Assessment Tool Input/Output Documentation. The limits used here are adequate with field analyses, when compared with the indicated values given by Arnold et al. (2012).

Table 2. Parameters of the sensitivity analysis related to water production.

\begin{tabular}{|c|c|c|c|c|c|}
\hline Parameter & Description & Unit & LL & LU & $\begin{array}{l}\text { Method of } \\
\text { variation }\end{array}$ \\
\hline ALPHA_BF & Baseflow alpha factor & day & 0 & 1 & Replace \\
\hline BIOMIX & Biological mixing efficiency & $1-1$ & 0 & 1 & Replace \\
\hline BLAI & Maximum potential leaf area index & $\mathrm{m}^{2} \mathrm{~m}^{-2}$ & 0 & 1 & Replace \\
\hline CANMX & Maximum canopy storage & $\mathrm{mm}$ & 0 & 10 & Replace \\
\hline CH_K2 & $\begin{array}{l}\text { Effective hydraulic conductivity in the main } \\
\text { channel alluvium }\end{array}$ & $\mathrm{mm} \mathrm{h}^{-1}$ & 0 & 150 & Replace \\
\hline CH_N2 & Manning's "n" value for the main channel & $\mathrm{s} \mathrm{m}^{-3}$ & 0 & 1 & Replace \\
\hline $\mathrm{CN} 2$ & $\begin{array}{l}\text { Initial SCS runoff curve number for moisture } \\
\text { condition II }\end{array}$ & $1-1$ & $-25 \%$ & $25 \%$ & Relative \\
\hline EPCO & Plant uptake compensation factor & $1-1$ & 0 & 1 & Replace \\
\hline ESCO & Soil evaporation compensation factor & $1-1$ & 0 & 1 & Replace \\
\hline GW_DELAY & Groundwater delay time & day & -10 & 10 & Add \\
\hline GW_REVAP & Groundwater "revap" coefficient & $1-1$ & $-0,036$ & 0,036 & Add \\
\hline GWQMN & $\begin{array}{l}\text { Threshold depth of water in the shallow } \\
\text { aquifer required for return flow to occur }\end{array}$ & $\mathrm{mm}$ & -1000 & 1000 & Add \\
\hline REVAPMN & $\begin{array}{l}\text { Threshold depth of water in the shallow } \\
\text { aquifer for "revap" or percolation to the deep } \\
\text { aquifer to occur }\end{array}$ & $\mathrm{mm}$ & -100 & 100 & Add \\
\hline SOL_ALB & Moist soil albedo & $1-1$ & $-25 \%$ & $25 \%$ & Relative \\
\hline SOL_AWC & Available water capacity of the soil layer & $\mathrm{mm} \mathrm{mm}^{-1}$ & $-25 \%$ & $25 \%$ & Relative \\
\hline SOL_K & Saturated hydraulic conductivity & $\mathrm{mm} \mathrm{h}^{-1}$ & $-25 \%$ & $25 \%$ & Relative \\
\hline SOL_Z & Depth from soil surface to bottom of layer & $\mathrm{mm}$ & $-25 \%$ & $25 \%$ & Relative \\
\hline SURLAG & Surface runoff lag coefficient & day & $-25 \%$ & $25 \%$ & Relative \\
\hline TLAPS & Temperature lapse rate & ${ }^{\circ} \mathrm{C} \mathrm{km}^{-1}$ & 0 & 10 & Replace \\
\hline SLSUBBSN & Average slope length & $\mathrm{m}$ & 0 & 50 & Replace \\
\hline
\end{tabular}

Four sensitivity tests were performed to verify the influence of the amount of input data (length of historical records of flows and fluviometric station location) and the number of variations in the values of each parameter within the range present in Table 1 (iterations) during the analysis. The tests are listed below:

- 1st Test: long historical records (1987 to 2015) flow data from the Fazenda Jucuruaba fluviometric station with 300 iterations;

- 2nd Test: long historical records (1987 to 2015) flow data from the Córrego do Galo fluviometric station with 300 iterations;

- 3rd Test: same characteristics as the 2nd Test, but with 100 iterations;

- 4th Test: short historical records (2013 to 2015) flow data from the Córrego do Galo fluviometric station with 300 iterations.

The results obtained by the sensitivity analyses were evaluated by the t-stat and p-values. The first provides the sensitivity measure, where the higher its value the more sensitive the parameter is. The second determines the significance of the sensitivity, where a value close to zero indicates greater significance provided by SWAT-CUP. 


\section{RESULTS AND DISCUSSION}

The modeling results in SWAT divided the Jucu River Basin into 147 sub-basins, creating a total of 2,341 hydrological response units (HRU). The fluviometric station of Fazenda Jucuruaba was located in sub-basin Number 128 and Córrego do Galo in sub-basin Number 57.

The first sensitivity test generated the sensitivity hierarchy of the parameters presented in Figure 3-a according to p-value and t-stat values. The second test, based on the same characteristics as the first one, but with data from the Córrego do Galo fluviometric station, generated the results of Figure 3-b. The third test corresponds to the same characteristics of the second, but only 100 iterations were used (Figure 3-c). Finally, the fourth test was constructed with short historical records of 3 years (2013 to 2015), with flow data from the Córrego do Galo fluviometric station, using 300 iterations (Figure 3-d).

Van Griensven et al. (2006) suggest the classification of parameters regarding their sensitivity by means of the increasing hierarchical position of the parameters. Thus, the parameters can be categorized as very important (1st), important (2nd-6th), slightly important (7th-14th) and not important (15th-20th).

For each test, the parameters considered as very important and important according to Van Griensven et al. (2006) correspond to the first six parameters with the lowest values of $p$-value and higher values (in module) of t-stat. They are presented below in descending order of sensitivity for the four tests:

- 1st test - ALPHA_BF, SOL_Z, GW_DELAY, CN2, SOL_K, and ESCO;

- 2nd test - ALPHA_BF, SOL_Z, GW_DELAY, ESCO, CN2, and CH_K2;

- 3rd test - ALPHA_BF, SOL_Z, GW_DELAY, SOL_K, CH_K2, and CANMX;

- 4th test -SOL_Z, ALPHA_BF, GWQMN, GW_DELAY, CN2, and SOL_K.

In terms of sensitivity in predicting superficial flow rates, note that some parameters are important in some tests, while not in others. For example, the ESCO parameter is important in the 1st and 2nd tests, although in the 3rd test it is considered slightly important and not important in the 4th test. Thus, the ESCO parameter can be turned into one of the most- or leastsensitive parameters for the same region under study depending on the methodology used.

From the results (Figure 3), the least-sensitive parameters (the six with the major p-values in Figure 3) were categorized as "not important"; but in other tests, some were kept in the "not important" while others moved to the "slightly important" category. Even though that was expected, some parameters are generally less-sensitive, such as BLAI, REVAPMN, and CH_N2, while the most-sensitive are ALPHA_BF, SOL_Z, GW_DELAY, and CN2.

For each performance used on the input data, such as length of historical records, fluviometric station chosen or the number of iterations used during the analysis-sensitivity process, there is a different list and sequence of sensitivity parameters. Even Abbaspour et al. (2018), the main developer of the SWAT sensitivity analysis method, affirms that sensitivity analysis provides information about the most important process-drivers in the study region, according to local characteristics.

Therefore, the most sensitivity parameters should be analyzed for each study region, since the input data (land use, pedology, physical characteristics of the watershed and climatic data) are different. Besides, this paper indicates the use of different performances in analysis sensitivity in order to make the best choice of the most influential parameters on flow estimation. Each performance should be well-justified, such as the length of historical records, monitoring stations, number of iterations, minimum interval, maximum interval and method of variation of each during the sensitivity analysis. 
A
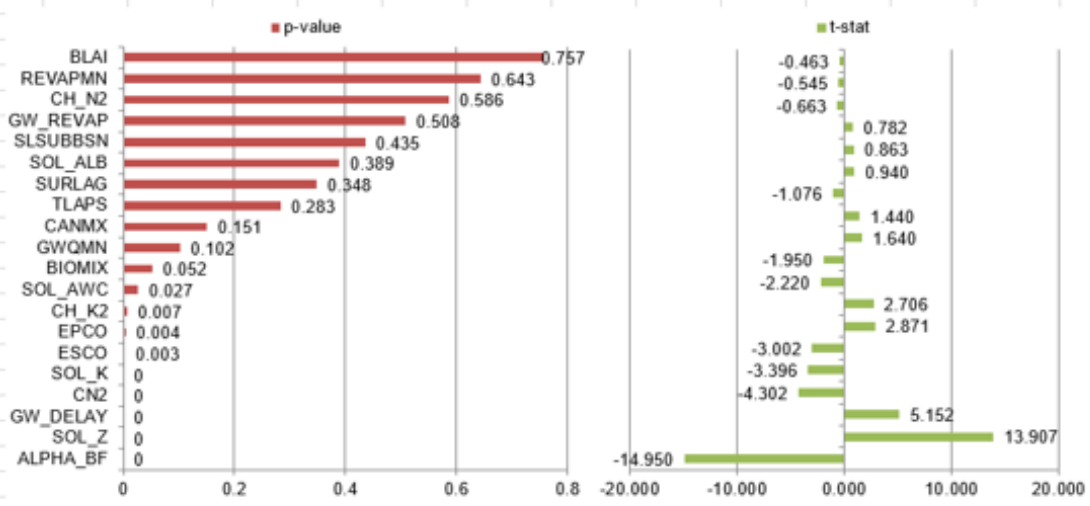

B
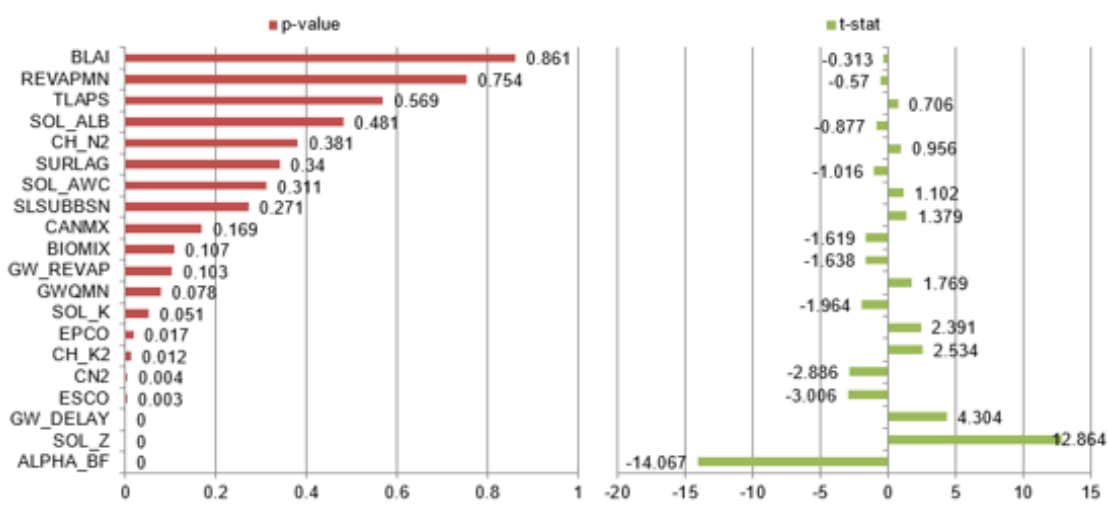

C
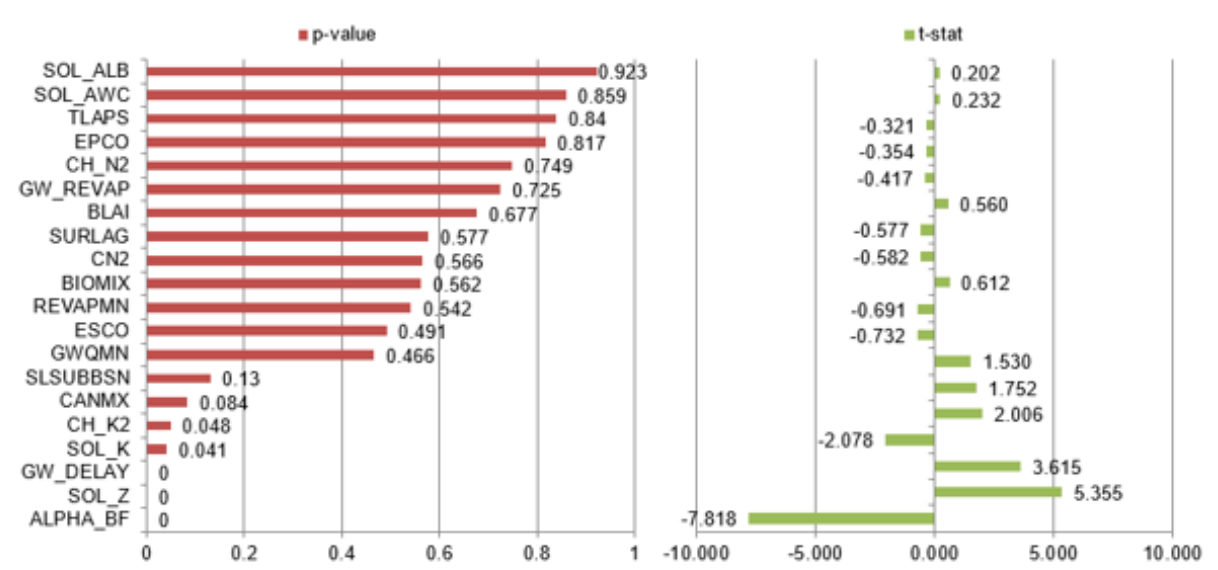

D
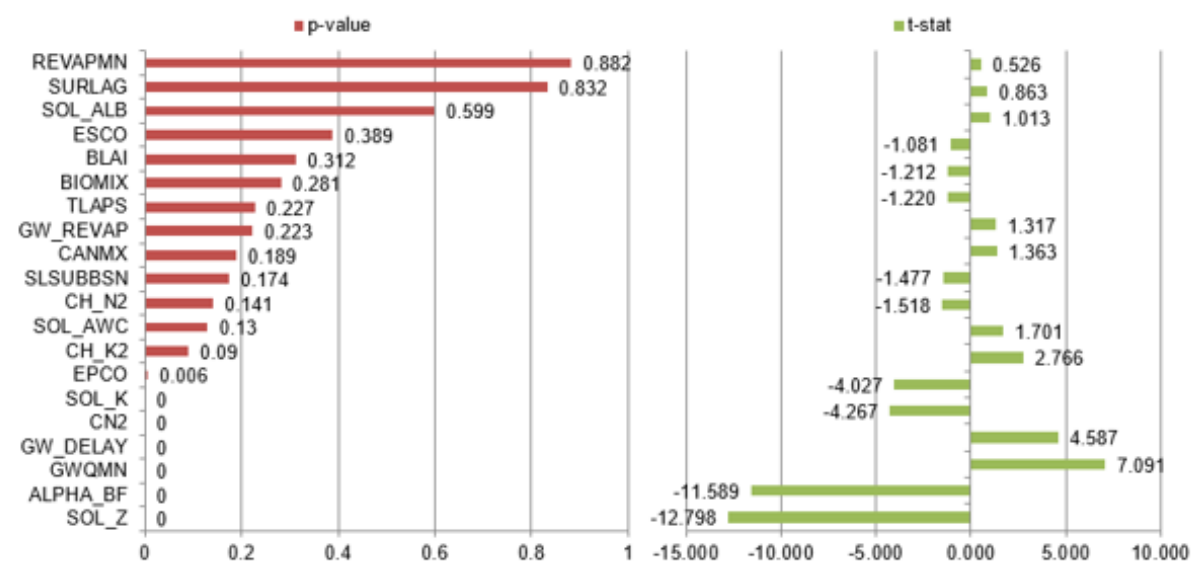

Figure 3. Sensitivity of flow parameters for the first (A), second (B), third (C) and fourth (D) tests. 
In this case study, we opted for the five common parameters obtained in the first and second alternatives, since the calibration tests used flow data from both fluviometric stations. The number of iterations considered appropriate corresponds to these alternatives because the SWAT-CUP developer recommends it. Lastly, the largest historical records available encompass a more-extensive series of flood and drought events.

In summary, the parameters considered the most sensitive for the study region are: basal recession constant (ALPHA_BF), depth from soil surface to bottom of layer (SOL_Z), recharge time of the shallow aquifer (GW_DELAY), evaporation compensation factor (ESCO) and the SCS runoff curve number for moisture condition II (CN2).

\section{CONCLUSIONS}

The study investigated how methodological procedures (changing input variables and the number of iterations) can influence the ranking of sensitive parameters on the SWAT model. The primary conclusions reached are summarized as:

- The sensitivity of the hydrologic parameters of the SWAT model not only depends on the physiographic and climatic variables of the study area, but also on the procedures used in the sensitivity analysis. The SWAT-CUP sensitivity analysis using the SUFI-2 algorithm obtained different parameter hierarchies. It emphasizes the relevance of a greater detailing of methodological processes used in the sensitivity analysis, considering that different hierarchies of parameters can be obtained through the same tool.

- Besides characteristics from the study area, all the procedures used to formulate the sensitivity analysis scenarios, such as variation in the number of iterations, fluviometric station location and length of historical records, affected significantly the results of sensitive parameters for estimating flow rate in the Jucu River Basin. Therefore, it is important that each study region that uses the SWAT model to predict superficial flow rates perform different procedures in sensitivity analysis to correctly determine the most sensitive parameters.

- Among the range of input variables of the model, pedological variables were the ones that presented the highest sensitivity for the Jucu River Basin.

We recommend the application of similar tests using other algorithms, rather than SUFI2, for parameter sensitivity analysis to estimate mean flows. In this way, it would be possible to investigate how those methodological procedures affect the results by the use of different sensitivity techniques.

\section{REFERENCES}

ABBASPOUR, K. C.; YANG, J.; MAXIMOV, I.; SIBER, R.; BOGNER, K.; MIELEITNER, J. et al. Modelling hydrology and water quality in the pre-alpine/alpine Thur watershed using SWAT. Journal of Hydrology, v. 333, n. 2-4, p. 413-430, 2007. http://dx.doi.org/10.1016/j.jhydrol.2006.09.014

ABBASPOUR, K. C.; ROUHOLAHNEJAD, E.; VAGHEFI, S.; SRINIVASAN, R.; YANG, H.; KLØVE, B. A continental-scale hydrology and water quality model for Europe: Calibration and uncertainty of a high-resolution large-scale SWAT model. Journal of Hydrology, v. 524, p. 733-752, 2015. https://dx.doi.org/10.1016/j.jhydrol.2015.03.027 
ABBASPOUR, K. C.; VAGHEFI, S. A.; SRINIVASAN, R. A Guideline for Successful Calibration and Uncertainty Analysis for Soil and Water Assessment: A Review of Papers from the 2016 International SWAT Conference. Water, v. 10, n. 6, p. 1-18, 2018. https://dx.doi.org/10.3390/w10010006

ABBASPOUR, K. C.; FARAMARZI, M.; GHASEMI, S. S.; YANG, H. Assessing the impact of climate change on water resources in Iran. Water Resources Research, v. 45, p. 1-16, 2009. http://dx.doi.org/10.1029/2008WR007615

AGÊNCIA NACIONAL DE ÁGUAS (Brasil). Portal Hidroweb. 2016. Available at: http://www.snirh.gov.br/hidroweb. Access in: June 2016.

ARNOLD, J. G.; KINIRY, J. R.; SRINIVASAN, R.; WILLIAMS, J. R.; HANEY, E. B.; NEITSCH, S. L. Input/Output Documentation. Version 2012. Atlanta: Texas Water Resources Institute, 2012.

ARNOLD, J. G.; SRINIVASAN, R.; MUTTIAH, R. S.; WILLIAMS, J. R. Large area hydrologic modeling and assessment - Part I: Model development. Journal of American Water Resource Association, v. 34, p. 73-89, 1998. https://dx.doi.org/10.1111/j.17521688.1998.tb05961.x

BRIGHENTI, T. M.; BONUMÁ, N. B.; CHAFFE, P. L. B. Hierarchical Calibration of SWAT model for a watershed in southern Brazil. Revista Brasileira de Recursos Hídricos, v. 21, n. 1, p. 53-64, 2016. http://dx.doi.org/10.21168/rbrh.v21n1.p53-64

BROUZIYNE, Y.; ABOUABDILLAH, A.; BOUABID, R.; OUESLATI, O. SWAT manual calibration and parameters sensitivity analysis in a semi-arid watershed in North-western Morocco. Arabian Journal Of Geosciences, v. 10, n. 19, p.1-13, 2017. http://dx.doi.org/10.1007/s12517-017-3220-9

DA SILVA, M.; DE AGUIAR NETTO, A.; DE JESUS NEVES, R.; DO VASCO, A.; ALMEIDA, C.; FACCIOLI, G. Sensitivity Analysis and Calibration of Hydrological Modeling of the Watershed Northeast Brazil. Journal of Environmental Protection, v. 6, p. 837-850, 2015. https://dx.doi.org/10.4236/jep.2015.68076

EMPRESA BRASILEIRA DE PESQUISA AGROPECUÁRIA (EMBRAPA). Levantamento de reconhecimento dos solos do estado do Espírito Santo. 1978. Available at: https://www.embrapa.br/busca-de-publicaNSEs/-/publicacao/335800/levantamento-dereconhecimento-dos-solos-do-estado-do-espirito-santo. Access in: August 2016.

FATICHI, S.; VIVONI, E. R.; OGDEN, F. L.; IVANOV, V. Y.; MIRUS, B.; GOCHIS, D. et al. An overview of current applications, challenges, and future trends in distributed process-based models in hydrology. Journal of Hydrology, v. 537, p. 45-60, 2016. https://dx.doi.org/10.1016/j.jhydrol.2016.03.026

FRANCESCONI, W.; SRINIVASAN， R.; PÉREZ-MIÑANA， E.; WILLCOCK， S.; QUINTERO, M. Using the Soil and Water Assessment Tool (SWAT) to model ecosystem services: A systematic review. Journal of Hydrology, v. 535, p. 625-636, 2016. https://dx.doi.org/10.1016/j.jhydrol.2016.01.034

GOLMOHAMMADI, G.; RUDRA, R.; DICKINSON, T.; GOEL, P.; VELIZ, M. Predicting the temporal variation of flow contributing areas using SWAT. Journal of Hydrology, v. 547, p. 375-386, 2017. https://dx.doi.org/10.1016/j.jhydrol.2017.02.008 
INSTITUTO BRASILEIRO DE GEOGRAFIA E ESTATÍSTICA (IBGE). Estimativa da população de 2017. Available at: https://www.ibge.gov.br/estatisticasnovoportal/sociais/populacao/9103-estimativas-de-populacao.html?=\&t=o-que-e.

Access in: June 2018.

INSTITUTO CAPIXABA DE PESQUISA, ASSISTÊNCIA TÉCNICA E EXTENSÃO RURAL (INCAPER). Meteorologia. 2016. Available at: https://meteorologia.incaper.es.gov.br. Access in: June 2016.

INSTITUTO ESTADUAL DE MEIO AMBIENTE E RECURSOS HÍDRICOS (IEMA). Geobases. 2007. Available from: https://geobases.es.gov.br. Access in: Jul. 2016.

KOUCHI, D. H.; ESMAILI, K.; FARIDHOSSEINI, A.; SANAEINEJAD, S. H.; KHALILI, D.; ABBASPOUR, K. C. Sensitivity of Calibrated Parameters and Water Resource Estimates on Different Objective Functions and Optimization Algorithms. Water, v. 9, n. 384, p. 1-16, 2017. https://dx.doi.org/10.3390/w9060384

LAMBA, J.; THOMPSON, A. M.; KARTHIKEYAN, K. G.; PANUSKA, J. C.; GOOD, L. W. Effect of best management practice implementation on sediment and phosphorus load reductions at subwatershed and watershed scale using SWAT model. International

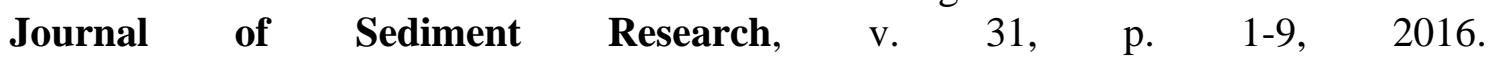
https://dx.doi.org/10.1016/j.ijsrc.2016.06.004

PONTES, L. M.; VIOLA, M. R.; SILVA, M. L. N.; BISPO, D. F. A.; CURI, N. Hydrological Modeling of Tributaries of Cantareira System, Southeast Brazil, with the Swat Model. Engenharia Agrícola, v. 36, n. 6, p. 1037-1049, 2016. http://dx.doi.org/10.1590/18094430-Eng.Agric.v36n6p1037-1049/2016

ROMAGNOLI, M.; PORTAPILA, M.; RIGALLI, A. Assessment of the SWAT model to simulate a watershed with limited available data in the Pampas region, Argentina. Science Of The Total Environment, v. 596-597, p. 437-450, 2017. http://dx.doi.org/10.1016/j.scitotenv.2017.01.041

SAHU, M.; LAHARI, S.; GOSAIN, A. K.; OHRI, A. Hydrological Modeling of Mahi Basin Using SWAT. Journal of Water Resource and Hydraulic Engineering, v. 5, p. 68-79, 2016. http://dx.doi.org/10.5963/JWRHE0503001

SARRAZIN, F.; PIANOSI, F.; WAGENER, T. Global Sensitivity Analysis of environmental models: Convergence and validation. Environmental Modelling \& Software, v. 79, p. 135-152, 2016. https://dx.doi.org/10.1016/j.envsoft.2016.02.005

SONG, X.; ZHANG, J.; ZHAN, C.; XUAN, Y.; YE, M.; XU, C. Global sensitivity analysis in hydrological modeling: Review of concepts, methods, theoretical framework, and applications. Journal of Hydrology, v. 523, p. 739-757, 2015. https://dx.doi.org/10.1016/j.jhydrol.2015.02.013

TEGEGNE, G.; PARK, D. K.; KIM, Y. Comparison of hydrological models for the assessment of water resources in a data-scarce region, the Upper Blue Nile River Basin. Journal Of Hydrology: Regional Studies, v. 14, p. 49-66, 2017. http://dx.doi.org/10.1016/j.ejrh.2017.10.002

VAN GRIENSVEN, A.; MEIXNER, T.; GRUNWALD, S.; BISHOP, T.; DILUZIO, M.; SRINIVASAN, R. A global sensitivity analysis tool for the parameters of multi-variable catchment models. Journal of Hydrology, v. 324, p. 10-23, 2006. https://dx.doi.org/10.1016/j.jhydrol.2005.09.008 
WU, Y.; LIU, S. Automating calibration, sensitivity and uncertainty analysis of complex models using the R package Flexible Modeling Environment (FME): SWAT as an example. Environmental Modelling \& Software, v. 31, p. 99-109, 2012. http://dx.doi.org/10.1016/j.envsoft.2011.11.013

ZHANG, D.; CHEN, X.; YAO, H.; JAMES, A. Moving SWAT model calibration and uncertainty analysis to an enterprise Hadoop-based cloud. Environmental Modelling \& Software, v. 84, p. 140-148, 2016. https://dx.doi.org/10.1016/j.envsoft.2016.06.024

ZADEH, F. K.; NOSSENT, J.; SARRAZIN, F.; PIANOSI, F.; GRIENSVEN, A. V.; WAGENER, T. et al. Comparison of variance-based and moment-independent global sensitivity analysis approaches by application to the SWAT model. Environmental $\begin{array}{lllllll}\text { Modelling \& Software, } & \text { v. 91, p. 210-222, }\end{array}$ https://dx.doi.org/10.1016/j.envsoft.2017.02.001 